\begin{tabular}{cc|c}
\hline Tar. Bil. Der. & Journal of Agricultural Sciences \\
& $\begin{array}{c}\text { Dergi web sayfası: } \\
\text { www.agri.ankara.edu.tr/dergi }\end{array}$ & Journal homepage: \\
& www.agri.ankara.edu.tr/journal
\end{tabular}

\title{
Effects of Weaning Ages on the Growth, Feed Conversion Efficiency and Some Behavioral Traits of Brown Swiss x Eastern Anatolian Red F Calves
}

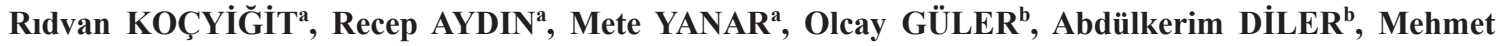 \\ AVCI ${ }^{a}$, Selçuk ÖZYÜREKc, Dilek KABAKCI ${ }^{\mathrm{a}}$ Elif Nur HİRİK ${ }^{\mathrm{a}}$ \\ ${ }^{a}$ Atatürk University, Faculty of Agriculture, Department of Animal Science, Erzurum, TURKEY \\ ${ }^{\boldsymbol{b}}$ Atatürk University, Hinis Vocational School, Department of Veterinary Laboratory and Health, Hinis, Erzurum, TURKEY \\ ${ }^{c}$ Erzincan University, Çayırlı Vocational School, Department of Food Processing, Çayırll, Erzincan, TURKEY
}

\section{ARTICLE INFO}

Research Article DOI: 10.1501/Tarimbil_0000001352

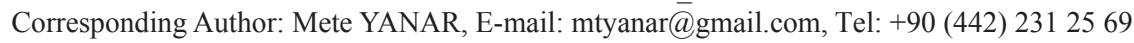

Received: 06 May 2014, Received in Revised Form: 25 August 2014, Accepted: 26 September 2014

\begin{abstract}
The purpose of this research was to investigate the possibility of the reducing weaning age of Brown Swiss $\mathrm{x}$ Eastern Anatolian Red $F_{1}$ crossbred calves reared in North East Region of Anatolia. A total of 26 calves were housed in individual hutches and weaned at 2 (early weaning) or 3 (late weaning) months of age. While weaning weight of the calves in different weaning age treatment groups was significantly $(\mathrm{P}<0.01)$ different in favor of calves weaned lately, 6 months weight was not significantly affected by ages of weaning. Average 6 months weight of the male calves was significantly $(\mathrm{P}<0.05)$ higher than that of female calves. The effects of weaning ages on the weight gain in both post-weaning and overall periods of the trial were not significant. Total milk dry matter intake (DMI) of the late weaned calves were significantly $(\mathrm{P}<0.01)$ greater than that of early weaned calves. However, starter DMI of the calves weaned 2 months of age was higher $(\mathrm{P}<0.05)$ than that of late weaned calves, but dry hay and total feed DMI were not affected by the weaning ages. Sex of the calves also did not result in significant effects on the milk, dry hay, starters and total feed DMI. Feed conversion efficiency in a period between birth and 6 months of age were not significantly affected by weaning ages. The weaning age and sex of calves did not significantly affect the gains in body measurements. Percentage of time spent for lying, standing, eating and drinking water behaviors were not also significantly affected by both weaning ages and sex of calves. The results of this study suggested that the crossbred calves could be weaned successfully at 2 months of age without having adverse effect on their growth, feed conversion efficiency and behavioral traits.
\end{abstract}

Keywords: Early weaning; Feed intake; Growth performance; Behavior; Feed conversion efficiency

\section{Sütten Kesim Yaşlarının Esmer x Doğu Anadolu Kırmızısı F Buzağılarında Büyüme, Yemden Yararlanma Oranı ve Bazı Davranış Özellikleri Üzerine Etkileri}

\section{ESER BILGISII}

Araştırma Makalesi

Sorumlu Yazar: Mete YANAR, E-posta: mtyanar@gmail.com, Tel: +90 (442) 2312569

Geliş Tarihi: 06 Mayıs 2014, Düzeltmelerin Gelişi: 25 Ağustos 2014, Kabul: 26 Eylül 2014 


\section{ÖZET}

Bu çalışmanın amacı, Kuzey Doğu Anadolu Bölgesi’nde yetiştirilen Esmer x Doğu Anadolu Kırmızısı F melezi buzağıların sütten kesim yaşının düşürülme imkânlarını araştırmaktır. Toplam 26 buzağı bireysel bölmelerde barındırılarak 2 (erken sütten kesim) veya 3 (geç sütten kesim) aylık yaşlarda sütten kesilmişlerdir. Sütten kesim ağırlığ geç sütten kesilen buzağılar lehine önemli $(\mathrm{P}<0.01)$ derecede farklı iken, 6 ay ağırlı̆̆ sütten kesim yaşından önemli derecede etkilenmemiştir. Erkek buzağıların 6 ay ağırlıkları önemli derecede $(\mathrm{P}<0.05)$ dişi buzağılardan daha yüksek bulunmuştur. Sütten kesim yaşının sütten kesim sonrası ve tüm deneme süresince canlı ağırlık artışı üzerine etkisi önemli olmamıştır. Toplam süt kuru madde tüketimi, geç sütten kesilen buzağılarda erken sütten kesilenlere göre önemli derecede $(\mathrm{P}<0.01)$ daha yüksek bulunmuştur. Ancak, 2 aylık yaşta sütten kesilen buzağıların kesif yem kuru madde alımı geç sütten kesilenlerden daha yüksek iken $(\mathrm{P}<0.05)$, kuru ot ve toplam yem kuru madde tüketimleri sütten kesim yaşlarından etkilenmemiştir. Süt, kuru ot, kesif ve toplam yem kuru madde tüketimi üzerine buzağ cinsiyeti de önemli derecede etki yapmamıştır. Doğum 6 ay arası dönemde, yemden yararlanma oranı sütten kesim yaşlarından önemli derecede etkilenmemiştir. Sütten kesim yaşları ile buzağı cinsiyetinin, vücut ölçülerinde saptanan artışlar bakımından önemli etkileri olmamıştır. Yatma, ayakta durma, yem yeme ve su içme davranışları için harcanan zamanların oranları da, buzağıların sütten kesim yaşı ve cinsiyetlerinden önemli derecede etkilenmemiştir. Araştırma sonuçları, melez buzağıların büyüme, yemden yararlanma ve davranış özellikleri bakımından herhangi bir olumsuz durum oluşmaksızın başarılı bir şekilde 2 aylık yaşta sütten kesilebileceğini göstermiştir.

Anahtar Kelimeler: Erken sütten kesim; Yem tüketimi; Büyüme performansı; Davranış; Yemden yararlanma oranı

(c) Ankara Üniversitesi Ziraat Fakültesi

\section{Introduction}

North East Region of Turkey is very suitable for cattle production due to widespread pastures and geographical conditions. Since milk and meat yields of Eastern Anatolian Red (EAR) cattle which is predominant native cattle breed do not satisfy for cattle producers, most of EAR cows reared in this area have been crossed with Brown Swiss (BS), Holstein Friesian or Simmental sires in order to improve milk and beef production. Therefore, nowadays, $59.2 \%$ of the total cattle population in this part of Turkey is consisted of crosses of EAR with the European cattle breeds, and a large proportion of the crossbreds is formed by the crosses of EAR cows with BS sires.

One of the significant factors affecting profitability of the dairy enterprise is efficient growth of dairy calves (Quigley et al 2006). Calf feeding programs have also significant influence on the efficiency of the growth rate of the young animals. Early weaning of the calves is cost effective practice at moderate environmental conditions since it gets calves started on cheaper dry feeds sooner. Therefore, raising cost of the calves is reduced by transition from feeding of milk to feeding of dry feeds. Weaning ages of the calves reared in Turkey is highly variable and it varies from 70 to 180 days of age (Erez 2011).

Over the years, many studies (Ulutaş et al 1996; Koçak \& Güneş 2005; Kehoe et al 2007; Hill et al 2009) carried out on different cattle breeds showed no significant differences in body weights and weight gains of the calves weaned early or late in different phases of the growth. Uğur \& Yanar (1998), Uğur et al (2004) and Hill et al (2009) also reported that the weaning ages did not have significant influence on the feed conversion efficiency, while Bojarpour et al (2010) and Özkaya \& Toker (2012) indicated that early weaning tended to increase feed consumption of dairy calves.

Up to now, any experimental data on the effect of different weaning ages on the growth performance, feed intake, feed conversion efficiency and some behavioral traits of the $\mathrm{F}_{1}$ crossbred calves of Eastern Anatolian Red (EAR) cows with Brown Swiss (BS) sires reared in North East Region of Turkey has not been reported. Therefore, the study was carried out to compare growth performance, 
feed conversion efficiency, feed intake, gains in the body measurements, cost of weight gain as well as some behavioral traits of the calves weaned at 2 or 3 months of ages.

\section{Material and Methods}

The experiment was conducted at Research Farm of College of Agriculture (1821 m altitude, 39 55' 15.49' $\mathrm{N}$ latitude, $41^{\circ} 17^{\prime} 12.90 \mathrm{E}$ longitude) at Ataturk University, Erzurum, Turkey. Twenty six (14 female, 12 male) newborn $\mathrm{F}_{1}$ crossbred calves (BS ${ }^{\lambda} \mathrm{X} \mathrm{EAR}$ () ) were used in this study. The calves were born in late winter and early spring seasons. The calves were allowed to stay with their dam to receive colostrum for the first three days of their lives. Then, they were allocated randomly to two ages of weaning groups as early (weaning at 2 months of age) and late (weaning at 3 months of age) according to their sex. They were housed in a calf barn containing individual pens furnished by feeders and a plastic bucket during the study. The calves were fed with whole milk by using plastic bottles fitted with soft rubber nipples. The amount of milk fed calves was kept constant at $10 \%$ of their birth weight as suggested by Ulutaş et al (1996). The whole milk was fed to calves twice a day. All calves were weaned at either 2 months ( $\mathrm{n}=14$ animals) or 3 months ( $n=12$ animals) of age. Two different calf starters (starter I and II) and high quality dry hay were used during the experiment. Chemical composition of the feeds used in the study is presented in Table 1. While starter I was fed to calves between birth and 4 months of age, starter II was offered to the young animals between 4 and 6 months of ages. While the maximum quantity of the calf starters was $2 \mathrm{~kg}$ per day, the calves had ad libitum access to dry hay. The young animals were fed individually the calf starters and dry hay during the research period. Starter I and II remained in feeders were weighed daily and the amount of feed consumed was determined and recorded. Every morning, dry hay remained in the feeder was also collected and then weighed. Before fresh dry hay was put in the feeder, the amount of the fresh dry hay was also determined and recorded. The quantity of the fresh dry hay was higher than amount of dry hay which might be consumed daily by a calf. Therefore, the calf consumed dry hay as much as it desired (ad libitum feeding). Water was also supplied by a water bucket in the calf pens during the trial.

Table 1- Chemical composition of starters and dry hay used in the study

Çizelge 1- Çalışmada kullanılan kesif yemler ile kuru otun kimyasal kompozisyonu

\begin{tabular}{lccc}
\hline Nutrients & Starter I (\%) & Starter II (\%) & Dry hay (\%) \\
\hline Dry matter & 87.5 & 88.2 & 87.8 \\
Crude protein & 18.3 & 17.4 & 7.1 \\
Ether extract & 4.5 & 4.3 & 3.8 \\
Crude ash & 8.7 & 9.3 & 8.4 \\
Crude cellulose & 12.3 & 12.9 & 28.4 \\
\hline
\end{tabular}

The weights and body measurements such as body length, chest depth, heart girth, height at withers and fore-shank circumference were measured and recorded at birth, weaning and 6 months of age. Behavioral data were collected by instantaneous sampling method as explained by Martin \& Bateson (1993). In this method, behavior of an animal was determined and recorded once a week during 6 months by walking through the calf barn, at a distance from the calf pen at least $2.0 \mathrm{~m}$, every 15 min from 9.00 until 12.00 AM. Calves did not appear to be interested in or disturbed by the presence of the observer. The behavior was observed and recorded for each of the following activities by a method utilized by Kartal \& Yanar (2011) in which 1: eating (calf's head was in feed bucket), 2: drinking water (calf's head in water bucket), 3: lying (calf's body contacted bedding and ground), 4: standing (calf was inactive in upright position). First of all, number of observations belonging to each behavioral trait was found out. Then, percentage of time spent for each activity was calculated by dividing the number of observation for each trait to total quantities of the all observations. The result was expressed as a percentage by multiplying with 100 . Percentage time spent for each activity was calculated for a period between birth and 6 months of age. 
A 2 x 2 completely randomized factorial experimental design was used for statistical analysis of the data. The analysis of variance (ANOVA) was carried out by using SPSS (2004) statistics program. The interaction between weaning age and sex was excluded from the statistical model, since they were not significant in the preliminary statistical analysis. Behavioral data were also subjected to ANOVA, since they had normal statistical distribution. The statistical model used in the analysis is presented in Equation 1.

$\mathrm{Y}_{\mathrm{ijk}}=\mu+\mathrm{a}_{\mathrm{i}}+\mathrm{b}_{\mathrm{j}}+\mathrm{e}_{\mathrm{ijk}}$

where; $\mathrm{Y}_{\mathrm{ijk}}$, the measurement of a particular trait; $\mu$, the population mean; $a_{i}$, effects of weaning age $[i=1$ (2 months), 2 (3 months) $] ; b_{j}$, effects of sex [j = 1 (male), 2 (female)]; $\mathrm{e}_{\mathrm{ijk}}$, normally distributed random error with a mean of zero and variance $\sigma_{e}^{2}$.

\section{Results and Discussion}

Least square means with standard errors for weights obtained at birth, weaning and 6 months of age are presented in Table 2. The average weight of the calves weaned at 3 months of age was $21.09 \mathrm{~kg}$ heavier than that of calves weaned at 2 months of age $(\mathrm{P}<0.01)$. This result was in accordance with the findings of Uğur \& Yanar (1998), Koçak \& Güneş (2005) and Bajarpour et al (2010). The weight difference in favor of calves weaned at 3 months of age disappeared at 6 months of age. The weights obtained at 6 months of age were not affected significantly by the weaning age treatment. The result could be ascribed to the compensatory growth of the early weaned crossbred calves. Similarly, Bjorklund et al (2013) observed that 4-months weight of the calves weaned early (at 47 days) group did not differ from weights of calves in the mid (64 days) and late (90 days) groups.

Sex of the calves did not have significant effect on the weights obtained at birth and weaning. However, insignificant weight differences in favor of male calves at birth, weaning became significant $(\mathrm{P}<0.05)$ in 6 months of age. The average 6 months weight of male calves was $11.47 \mathrm{~kg}$ higher than that of female calves (Table 2). The result is in accordance with the finding of Uğur \& Yanar (1998).

The weaning age resulted in a significant $(\mathrm{P}<0.01)$ effect on the daily weight gain in the preweaning period in favor of late weaned calves (Table 3). Similarly, Laswai et al (2007) and Kisac et al (2011) reported that the calves fed milk longer time had the highest $(\mathrm{P}<0.01)$ average daily weight gain

Table 2- Least squares means and standard errors of weights $(\mathrm{kg})$ obtained from the crossbred calves at different ages

Çizelge 2- Melez buză̆ıların farklı yaşlarda belirlenen ağırlıklarına (kg) ait en küçük kareler ortalamaları ve standart hatalarl

\begin{tabular}{lcccc}
\hline & & Birth weight & Weaning weight & 6 months weight \\
\cline { 3 - 5 } & $N$ & $\bar{X} \pm S_{\bar{x}}$ & $\bar{X} \pm S_{\bar{x}}$ & $\bar{X} \pm S_{\bar{x}}$ \\
\hline Overall mean & 26 & $28.69 \pm 0.74$ & $63.79 \pm 1.69$ & $141.18 \pm 2.48$ \\
Weaning age & & & & \\
2 months & 14 & $29.04 \pm 1.01$ & $53.24 \pm 2.31$ & $140.53 \pm 3.38$ \\
3 months & 12 & $28.33 \pm 1.08$ & $74.33 \pm 2.48$ & $141.83 \pm 3.63$ \\
Level of significance & & $\mathrm{ns}$ & $* *$ & $\mathrm{~ns}$ \\
Sex & & & & \\
Female & 14 & $27.88 \pm 1.01$ & $62.08 \pm 2.31$ & $135.45 \pm 3.38$ \\
Male & 12 & $29.50 \pm 1.08$ & $65.50 \pm 2.48$ & $146.92 \pm 3.63$ \\
Level of significance & & $\mathrm{ns}$ & $\mathrm{ns}$ & $*$ \\
**, $\mathrm{P}<0.01 ; *, \mathrm{P}<0.05 ;$ ns, not significant & & &
\end{tabular}

Tarım Bilimleri Dergisi - Journal of Agricultural Sciences 21 (2015) 492-499 
in the pre-weaning period. In the present study, the weaning age effect on the weight gain disappeared in the post-weaning period. Overall daily weight gains in the period between birth and 6 months of age were not significantly different. All calves had a lower daily weight gain in the pre-weaning period of the growth, then, rate of weight gain increased with time as already reported by Ulutaş et al (1996) and Uğur et al (2004). Daily weight gains of the male calves in the post-weaning and overall periods in the present study were significantly $(\mathrm{P}<0.01)$ higher than those of the female calves. On the other hand, daily weight gains of the male and female calves in pre-weaning period did not differ significantly. Similar results were already reported by Yanar et al (2006) and Metin et al (2006).

Amounts of milk $(\mathrm{P}<0.01)$ and starters $(\mathrm{P}<0.05)$ DMI of the calves weaned at 2 months of age throughout the study was significantly different from those of calves weaned at 3 months of age (Table 4). The late weaned crossbred calves consumed 9.68 $\mathrm{kg}$ more milk dry matter (equal to $80.6 \mathrm{~kg}$ whole milk) than calves weaned at 2 months of age. On the other hand, late weaned calves consumed 23.21 $\mathrm{kg}$ less starter $(\mathrm{P}<0.05)$ than young animals weaned earlier. The result is in harmony with the findings of Khan et al (2007), Bojarpour et al (2010), Özkaya \& Toker (2012) and Rashid et al (2013). The reduction in calf starter intake of the young animals in the late weaning group could be due to prolonged milk feeding. Jasper \& Weary (2002) reported that increased intake of nutrients in liquid form generally causes less starter and forage intake in the dairy calves.

Least square means with standard error for feed conversion efficiencies in different phases of the growth of the crossbred calves are presented in Table 5. Feed conversion efficiency was in favor of late weaned calves $(\mathrm{P}<0.05)$ in the pre-weaning period. However, the same value was better for early weaned calves $(\mathrm{P}<0.01)$ in the post-weaning period. On the other hand, the difference between weaning age groups regarding feed conversion efficiency values obtained in the period between birth and 6 months of age was not statistically significant. Similar observation has already been reported by Kehoe et al (2007). The feed conversion efficiency values of male and female calves in pre- and postweaning periods did not differ significantly. The result is in harmony with the finding of Uğur \& Yanar (1998).

Table 3- Least squares means and standard errors of weight gains (kg) at various periods of the growth of crossbred calves

Çizelge 3- Melez buzağıların farklı büyüme dönemlerinde ağırlık artışlarına ait en küçük kareler ortalamaları ve standart hatalart

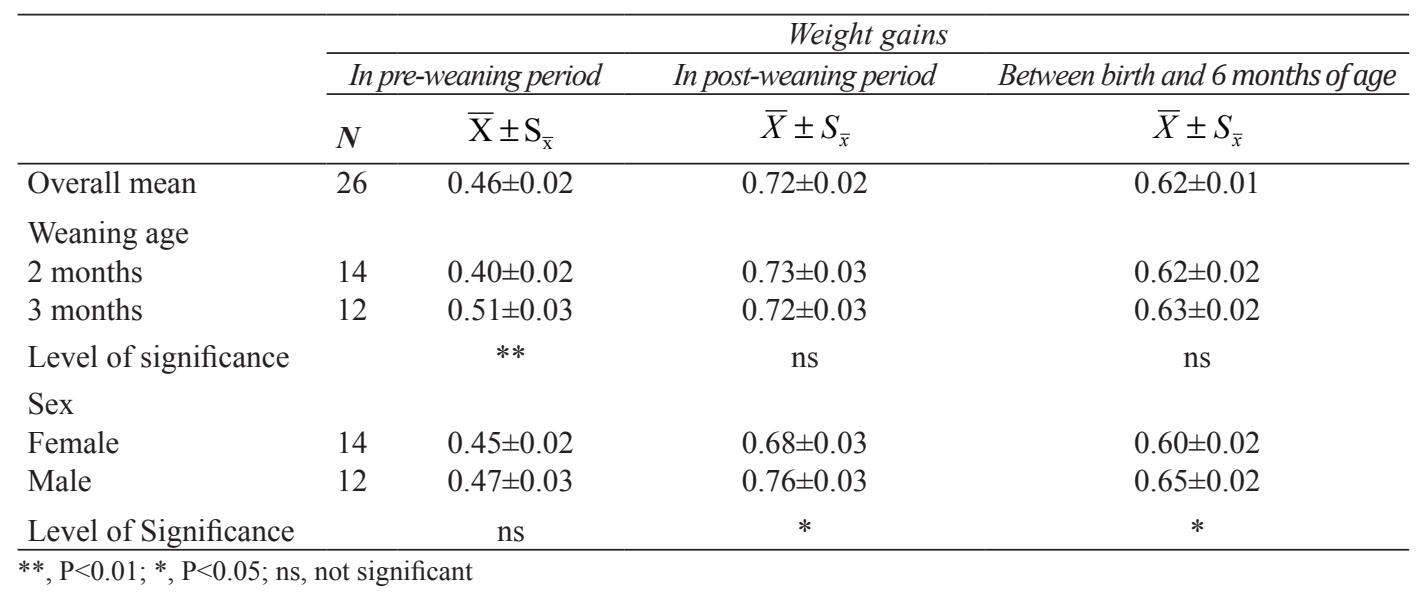


Table 4- Least square means and standard errors of milk, dry hay, starters and total feed dry matter intake of the calves between birth and 6 months of age

Çizelge 4- Doğum ile 6 aylık yaş arasında buzağıların süt, kuru ot, kesif yem ve toplam yem kuru madde alımına ait en küçük kareler ortalamalart ve standart hatalart

\begin{tabular}{|c|c|c|c|c|c|}
\hline & \multicolumn{5}{|c|}{ Total feed dry matter intake (kg) between birth and 6 months of age for } \\
\hline & \multicolumn{2}{|r|}{ Milk } & \multirow{2}{*}{$\frac{\text { Dry hay }}{\bar{X} \pm S_{\bar{x}}}$} & \multirow{2}{*}{$\begin{array}{c}\text { Starters } \\
\bar{X} \pm S_{\bar{x}}\end{array}$} & \multirow{2}{*}{$\begin{array}{c}\text { Total feed } \\
\bar{X} \pm S_{\bar{x}}\end{array}$} \\
\hline & $N$ & $\bar{X} \pm S_{\bar{x}}$ & & & \\
\hline Overall mean & 26 & $25.76 \pm 0.70$ & $76.99 \pm 1.95$ & $260.89 \pm 4.65$ & $363.64 \pm 6.06$ \\
\hline \multicolumn{6}{|l|}{ Weaning age } \\
\hline 2 months & 14 & $20.92 \pm 0.95$ & $78.37 \pm 2.66$ & $272.50 \pm 6.34$ & $371.79 \pm 8.26$ \\
\hline 3 months & 12 & $30.60 \pm 1.02$ & $75.60 \pm 2.86$ & $249.29 \pm 6.81$ & $355.49 \pm 8.87$ \\
\hline Level of significance & & $* *$ & ns & $*$ & ns \\
\hline \multicolumn{6}{|l|}{ Sex } \\
\hline Female & 14 & $25.09 \pm 0.95$ & $77.53 \pm 2.66$ & $258.28 \pm 6.34$ & $360.90 \pm 8.26$ \\
\hline Male & 12 & $26.43 \pm 1.02$ & $76.44 \pm 2.86$ & $263.51 \pm 6.81$ & $366.38 \pm 8.87$ \\
\hline Level of significance & & ns & ns & ns & ns \\
\hline
\end{tabular}

**, $\mathrm{P}<0.01 ; *, \mathrm{P}<0.05 ;$ ns, not significant

Table 5- Least square means and standard errors of feed conversion efficiencies of the calves at different periods of the growth

Çizelge 5- Büyümenin farklı dönemlerinde buzağıların yemden yararlanma değerlerine ait en küçük kareler ortalamalart ve standart hatalart

\begin{tabular}{|c|c|c|c|c|}
\hline & \multicolumn{4}{|c|}{ Feed conversion efficiency ${ }^{l}$} \\
\hline & & pre-weaning period & In post-weaning period & Between birth and 6 months of age \\
\hline & $N$ & $\bar{X} \pm S_{\bar{x}}$ & $\bar{X} \pm S_{\bar{x}}$ & $\bar{X} \pm S_{\bar{x}}$ \\
\hline Overall mean & 26 & $1.40 \pm 0.08$ & $4.22 \pm 0.11$ & $3.26 \pm 0.06$ \\
\hline Weaning age & & & & \\
\hline 2 months & 14 & $1.63 \pm 0.12$ & $3.84 \pm 0.15$ & $3,35 \pm 0.09$ \\
\hline 3 months & 12 & $1.17 \pm 0.12$ & $4.60 \pm 0.16$ & $3.17 \pm 0.09$ \\
\hline Level of significance & & * & $* *$ & ns \\
\hline Sex & & & & \\
\hline Female & 14 & $1.46 \pm 0.12$ & $4.42 \pm 0.15$ & $3.38 \pm 0.09$ \\
\hline Male & 12 & $1.34 \pm 0.12$ & $4.02 \pm 0.16$ & $3.14 \pm 0.09$ \\
\hline Level of significance & & ns & ns & ns \\
\hline
\end{tabular}

Gains in body measurements such as body length, hearth girth, height at withers, chest depth and fore-shank circumference were not significantly influenced by both the weaning age and sex of calves (Table 6). The results of body measurements are in agreement with the findings of the previous studies on calves weaned at different ages (Kehoe et al 2007; Rashid et al 2013).
In Table 7, least square means with standard errors for behavioral traits observed throughout the experiment are presented. Weaning age and sex did not result in significant differences in the average percentage of time spent for lying, standing, eating and drinking water behaviors during the entire research period. The data on the behavioral traits demonstrated that the weaning age did not affect 
Table 6- Least square means and standard errors of gains in body measurements of the crossbred calves (cm) between birth and 6 months of age

Çizelge 6- Doğum ile 6 aylık yaş arasında melez buzağıların vücut ölçülerindeki artışlara ait en küçük kareler ortalamalart ve standart hatalart

\begin{tabular}{|c|c|c|c|c|c|c|}
\hline & \multicolumn{2}{|c|}{ Height at withers } & Body length & Chest depth & Heart girth & Fore-shank circumference \\
\hline & $N$ & $\bar{X} \pm S_{\bar{x}}$ & $\bar{X} \pm S_{\bar{x}}$ & $\bar{X} \pm S_{\bar{x}}$ & $\bar{X} \pm S_{\bar{x}}$ & $\bar{X} \pm S_{\bar{x}}$ \\
\hline Overall mean & 26 & $29.83 \pm 0.93$ & $34.56 \pm 1.09$ & $18.33 \pm 0.55$ & $48.88 \pm 0.82$ & $3.63 \pm 0.18$ \\
\hline $\begin{array}{l}\text { Weaning age } \\
2 \text { months } \\
3 \text { months }\end{array}$ & $\begin{array}{l}14 \\
12\end{array}$ & $\begin{array}{l}30.49 \pm 1.27 \\
29.17 \pm 1.36\end{array}$ & $\begin{array}{l}33.49 \pm 1.49 \\
35.63 \pm 1.60\end{array}$ & $\begin{array}{l}18.03 \pm 0.75 \\
18.63 \pm 0.81\end{array}$ & $\begin{array}{l}47.92 \pm 1.11 \\
49.83 \pm 1.20\end{array}$ & $\begin{array}{l}3.80 \pm 0.24 \\
3.46 \pm 0.26\end{array}$ \\
\hline Level of significance & & ns & ns & ns & ns & ns \\
\hline $\begin{array}{l}\text { Sex } \\
\text { Female } \\
\text { Male }\end{array}$ & $\begin{array}{l}14 \\
12\end{array}$ & $\begin{array}{l}28.41 \pm 1.27 \\
31.25 \pm 1.36\end{array}$ & $\begin{array}{l}34.65 \pm 1.49 \\
34.46 \pm 1.60\end{array}$ & $\begin{array}{l}17.40 \pm 0.75 \\
19.25 \pm 0.81\end{array}$ & $\begin{array}{l}48.17 \pm 1.11 \\
49.58 \pm 1.20\end{array}$ & $\begin{array}{l}3.30 \pm 0.24 \\
3.96 \pm 0.26\end{array}$ \\
\hline Level of significance & & $\mathrm{ns}$ & $\mathrm{ns}$ & ns & $\mathrm{ns}$ & $\mathrm{ns}$ \\
\hline
\end{tabular}

Table 7- Least square means and standard errors of percentage of time spent on different activities of crossbred calves as affected by different weaning ages in a period between birth and 6 months of age

Çizelge 7- Doğum ve 6 aylık yaş arası periyotta farklı sütten kesim yaşları uygulanan melez buzağıların farklı aktiviteleri için harcanan zamanların oranlarına ait en küçük kareler ortalamaları ve standart hataları

\begin{tabular}{|c|c|c|c|c|c|}
\hline & \multicolumn{5}{|c|}{ Behavioral traits } \\
\hline & \multicolumn{2}{|c|}{ Standing (\%) } & \multirow{2}{*}{$\frac{\text { Lying (\%) }}{\bar{X} \pm S_{\bar{x}}}$} & \multirow{2}{*}{$\frac{\text { Eating (\%) }}{\bar{X} \pm S_{\bar{x}}}$} & \multirow{2}{*}{$\frac{\text { Drinking (\%) }}{\bar{X} \pm S_{\bar{x}}}$} \\
\hline & $N$ & $\bar{X} \pm S_{\bar{x}}$ & & & \\
\hline Overall mean & 26 & $25.52 \pm 0.74$ & $35.89 \pm 0.93$ & $37.54 \pm 0.85$ & $1.05 \pm 0.14$ \\
\hline $\begin{array}{l}\text { Weaning age } \\
2 \text { months } \\
3 \text { months }\end{array}$ & $\begin{array}{l}14 \\
12\end{array}$ & $\begin{array}{l}25.81 \pm 1.01 \\
25.24 \pm 1.08\end{array}$ & $\begin{array}{l}35.45 \pm 1.26 \\
36.33 \pm 1.36\end{array}$ & $\begin{array}{l}37.69 \pm 1.16 \\
37.39 \pm 1.25\end{array}$ & $\begin{array}{l}1.06 \pm 0.19 \\
1.04 \pm 0.20\end{array}$ \\
\hline Level of significance & & ns & ns & ns & ns \\
\hline $\begin{array}{l}\text { Sex } \\
\text { Female } \\
\text { Male }\end{array}$ & $\begin{array}{l}14 \\
12\end{array}$ & $\begin{array}{l}25.49 \pm 1.01 \\
25.56 \pm 1.08\end{array}$ & $\begin{array}{l}35.73 \pm 1.26 \\
36.05 \pm 1.36\end{array}$ & $\begin{array}{l}37.82 \pm 1.16 \\
37.26 \pm 1.25\end{array}$ & $\begin{array}{l}0.97 \pm 0.19 \\
1.13 \pm 0.20\end{array}$ \\
\hline Level of significance & & ns & ns & ns & $\mathrm{ns}$ \\
\hline
\end{tabular}

ns, not significant

the behavioral pattern of the calves. Weaning the calves at 2 months of age did not cause detrimental influence on the behavioral pattern of the calves.

Weaning ages had significant $(\mathrm{P}<0.01)$ effect on the cost of weight gain. Average feeding cost per $\mathrm{kg}$ weight gain of the calves weaned at 2 and 3 months of ages were $\$ 2.18$ and $\$ 2.41$ (4.28 and 4.71 Turkish Liras) respectively. The increased cost of calves weaned at 3 months of age was due to the extra amount of milk (average $80.6 \mathrm{~kg}$ per calves) offered to the young animals. Similarly, Bjorklund et al (2013) reported that total cost per $\mathrm{kg}$ of gain for the first 90 days of age was lowest for early weaned calves (\$3.02) and highest for late weaned animals (\$4.13). On the other hand, Laswai et al (2007) reported insignificant effects of the weaning age on the cost of weight gain of the calves reared in Tanzania. 


\section{Conclusions}

The results of this research suggest that it is possible to wean calves reared under the conditions of North East Turkey at 2 months of age without causing any detrimental effect on their growth performance. Further studies on the on weaning age earlier than 2 months should be conducted under these conditions.

\section{References}

Bojarpour M, Nargeskhani A \& Ghorbani M R (2010). Effects of weaning age on the growth and starter intake in Holstein calves. Journal of Animal Veterinary Advances 9(10): 1469-1471

Bjorklund E A, Heins B J \& Chester-Jones H (2013). Whole-milk feeding duration, calf growth, and profitability of group-fed calves in an organic production system. Journal of Dairy Science 96(11): 7363-7370

Jasper J \& Weary J M (2002). Effects of ad libitum milk intake on dairy calves. Journal of Dairy Science 85(11): 3054-3058

Erez I (2011). The effects of early weaning practice at performances of black and white calves. MS Thesis, Çukurova University (Unpublished), Turkey

Hill T, Bateman H G, Aldrich J M \& Schlotterbeck R L (2009). Effect of weaning age of dairy calves fed a conventional or more optimum milk replacer program. Professional Animal Scientist 25(5): 619624

Kisac P, Broucek J, Uhrincat M \& Hanus A (2011). Effect of weaning calves from mother at different ages on their growth and milk yield of mothers. Czech Journal of Animal Science 56(6): 261-268

Kartal T Z \& Yanar M (2011). Effect of floor types on the growth performance and some behavioural traits of Brown Swiss calves. Veterinarija Ir Zootechnika 55(77): 20-24

Kehoe S I, Dechow C D \& Heinrichs A J (2007). Effects of weaning age and milk feeding frequency on dairy calf growth, health and rumen parameters. Livestock Science 110(3): 267-272

Khan M A, Lee H J, Lee W S, Kim H S, Kim S B, Ki K S, Ha J K, Lee H G \& Choi Y J (2007). Pre- and postweaning performance of Holstein female calves fed milk through step-down and conventional methods. Journal of Dairy Science 90(2): 876-885
Koçak Ö \& Güneş H (2005). The growth and survival characteristics of Holstein female calves weaned at various ages. Turkish Journal of Veterinary and Animal Sciences 29(2): 511-516

Laswai G H, Lyimo H L N, Mtenga L A, Kimambo A E, Mgheni D M, Hvelplund T, Madsen J \& Weisbjerg M R (2007). Effects of local concentrate and weaning age on the performance of crossbred calves. Journal of Animal Feed Science 16(Suppl. 2): 419-423

Martin P \& Bateson P (1993). Measuring Behaviour: An Introductory Guide. Cambridge University Press, Cambridge

Metin J, Yanar M, Güler O, Bayram B \& Tüzemen N (2006). Growth, health and behavioural traits of dairy calves fed acidified whole milk. Indian Veterinary Journal 83(9): 976-979

Özkaya S \& Toker M T (2012). Effect of amount of milk fed, weaning age and starter protein level on growth performance in Holstein calves. Archives Tierzucht 55(3): 234-244

Quigley J D, Wolfe T A \& Elsasser T H (2006). Effects of additional milk replacer feeding on calf health, growth, and selected blood metabolites in calves. Jornal of Dairy Science 89(1): 207-216

Rashid M A, Pasha T N, Jabbar M A, IJAZ A, Rehman $H$ \& Yousaf M (2013). Influence of weaning regimen on intake, growth characteristics and plasma blood metabolites in male buffalo calves. Animal 7(9): 1472-1478

SPSS (2004). SPSS for Windows, Release 13.0. SPSS Inc., Chicago, Illinois

Uğur F \& Yanar M (1998). Effect of the different weaning ages on the growth and feed conversion efficiencies in Holstein-Friesian calves. Indian Journal of Animal Science 68(12): 1284-1286

Uğur F, Özhan M, Yanar M \& Tüzemen N (2004). Performance of calves fed a limited amount of milk in Eastern Anatolia conditions. Cuban Journal of Agricultural Science. 38(2): 125-128

Ulutaş Z, Akbulut Ö, Tüzemen N \& Özlütürk A (1996). Farklı sürelerde sütten kesilen D.A.K. buzağılarında büyüme ve gelişme. Lalahan Hayvancılık Araştırma Enstitüsü Dergisi 36(2): 54-67

Yanar M, Güler O, Bayram B \& Metin J (2006). Effects of feeding acidified milk replacer on the growth, health and behavioural characteristics of Holstein Friesian calves. Turkish Journal of Veterinary Animal Science 30(2): 235-241 